\title{
Pindola in Korea and Japan: Is the Wandering Jew Coming from East Asia?
}

\author{
Beatrix MECSI
}

\begin{abstract}
The legend of the Wandering Jew became very popular, especially from the $17^{\text {th }}$ century Western Europe. The story of punishment by eternal life until the next coming of Jesus Christ has parallels with the Buddhist legend of Pindola Bharadvaja, a disciple of Shakyamuni Buddha who was also punished by eternal life until the coming of the Future Buddha, Maitreya. The similarities were dealt with by the Japanese polymath, Minakata Kumagusu (1899) and Walter Edwards (1902) in the turn of the $20^{\text {th }}$ century, claiming that the story of the Wandering Jew was influenced by the Asian legends of Pindola.

In this paper I show that even if we do not have convincing evidences for proving any historical connections between these legends, the myth of eternal life as a punishment is an interesting idea, which appears in many traditions, forming layers on the existing and evergrowing traditions of myths and pictorial representations.
\end{abstract}

Keywords: The legend of the Wandering Jew, Pindola, Dokseong, the "Lonely Saint"

\section{Izvleček}

Legenda o potujočem Judu je postala zelo priljubljena, še posebej v Zahodni Evropi od 17. stoletja. Zgodba o večnem življenju kot kaznovanju do naslednjega prihoda Jezusa Kristusa ima vzporednice $z$ budistično legendo o Pindoli Bharadvaji, učencu Šakamunija Bude, ki je tudi bil kaznovan z večnim življenjem, dokler ni prišel Buda prihodnosti, Maitreja. Podobnosti sta obravnavala japonski polihistor Minakata Kumagusu (1899) in Walter Edwards (1902) na prelomu 20. stoletja, ki trdita, da so na zgodbo potujočega Juda vplivale azijske legende o Pindoli.

$\mathrm{V}$ tem prispevku bom pokazala, da tudi če nimamo prepričljivih dokazov za potrditev zgodovinskih povezav med temi legendami, je mit o večnem življenju kot kazni zanimiva ideja, ki se pojavlja v mnogih tradicijah in oblikuje plasti na obstoječih in vedno rastočih tradicijah mitov in njihovih ilustrativnih reprezentacijah.

Ključne besede: legenda potujočega Juda, Pindola, Dokseong, »Samotni svetnik«

\footnotetext{
* Beatrix MECSI, PhD, Associate Professor, Institute of East Asian Studies ELTE University Budapest, Hungary.bmecsi@gmail.com
} 


\section{Legend of the Wandering Jew}

The legend of the wandering Jew tells a story of a man from Jerusalem who refused Christ to have a rest in front of his house, and even used violence to chase him. When this happened Jesus told this man the following: "I'm leaving, but you have to wait until I come back" (Losonczi 2006). Since that time the man from Jerusalem would wander until the next coming of Jesus Christ according to the legends. (Mecsi et al. 2013) In fact, there is no reference to this story in the Bible. The legend does not even specify that the person who committed the sin against Christ was Jewish. Yet, there are some aspects which seem to be connected to the story: the possibility of immortality is mentioned in John $21,20-23$, while a sin committed against Jesus Christ is narrated in John 18, 19-22. (Losonczi 2006) Both "biblically" confirm the two main motifs of the myth of the Wandering Jew: aggression against Jesus Christ and an elongated lifespan until his return. As it was suggested by Losonczi (2006) ${ }^{1}$ the legend of the Wandering Jew was a Christian invention, but there are other opinions which argue for the Asian origin of the story.

As with legends, we can suppose an amalgamation of different beliefs and traditions, so it is very interesting how scholars are trying to connect the story to certain traditions. The legend of the wandering Jew reached the height of its popularity in $17^{\text {th }}-18^{\text {th }}$ centuries.

Serious authors referred to the Wandering Jew, sometimes without any link to the biblical background or without a Jewish protagonist. In the Dutch speaking

\footnotetext{
${ }^{1}$ Losonczi in her study (2006) deals with the legend of the Wandering Jew in the period between the $12-17^{\text {th }}$ centuries, the parallels and models in written and pictorial sources. She points out that the Crusades had a huge role in the Eastern legends and stories spreading in Western Europe. Most of them came through the Italian peninsula to Europe, and indeed here we find the first written example of the legend. The first mention of the legend seems to go back to 1223, to the Ignoti monachi Cisterciensis S. Mariae de Ferraria chronica et Ryccardi de Sancto Germano chronica priora, an account from Bologna, Italy. In 1228, the same story is found in Britain, in the Flores Historiarum chronicle, written by Roger of Wendover, a Benedictine monk in St. Albans. There is no evidence that the monks in St. Albans knew the earlier Italian version. These early sources say that Armenia was the place where they met the Wandering Jew, but in the Middle Ages Armenia often meant the Middle-East, and the eastern origin of the story probably is not a coincidence. (Losonczi 2006)

Around the 1400s, there are several accounts about the Wandering Jew from the Holy Land, such as the one about the envoy of the Portuguese King, the Flemish Jan Aerts van Mechelen. He went to Jerusalem in 1484 and reported a mysterious meeting with a Jew called Jan Baudewyn. Baudewyn was kept behind eight doors and could be seen only with the permission of the sultan, because his supernatural powers converted any viewer to Christian religion. In that text the sin against Jesus Christ is mentioned together with the punishment of staying on Earth until the second coming of Jesus Christ. (Losonczi 2006)
} 
countries, August Vermeylen is probably the best known author who wrote a book along these lines. The theme of the "Flying Dutchman" is also about somebody suffering his whole life because of something wrong he did, but in fact there is no immediate connection with the Wandering Jew. In the Koran too, there is a story of a never-resting protagonist, in the so-called "Al-Samiri”. (Mecsi et al. 2013)

\section{Asian Origins of the Legend of the Wandering Jew?}

Minakata Kumagusu (1867-1941), a polymath from Japan, when coming to study in Europe at the end of the $19^{\text {th }}$ century, noticed the similarities between the story of the Wandering Jew and the Asian story of Pindola Bharadvaja, one of the disciples of Shakyamuni Buddha, and published an article "The Wandering Jew" in the Notes and Queries in year 1899 (Minakata 1899). There were also some other scholars who attempted to connect the two stories, supposing a link between the Buddhist and Christian legends (Edmunds 1902).

Pindola Bharadvaja, one of the four Arhats or "spiritual practitioners" who realized a high stage of attainment (de Visser 1923, 6) were asked by the Buddha to propagate Buddhist law (Dharma) after he enters Parinirvana (de Visser 1923, 58). According to the earliest Indian sutras each of the four was associated with one of the four compass directions, to spread Buddha's message.

Pindola Bharadvaja is considered as one of the most important arhats according to several legends. His veneration has preceded the common in-temple veneration of Arhats in groups of 16 or 500. His name refers to his role as a protector of refectories (Sanskrit pinda $=$ alms, food for monks). ${ }^{2}$ We have evidence that in China by the $5^{\text {th }}$ century CE the cult of Arhat Pindola was already existent, due to a $457 \mathrm{CE}$ translation of the "Ching binlutou fa" ("Method of Inviting Pindola") into Chinese, Taishō 1689, 32, 784b-c (Kent 1995, 16, note 11)

Apart from the stories he was discussed in relation with food and food offering, the most interesting episodes are concerning Pindola's punishment with an eternal life, until the coming of Maitreya, the Buddha of the Future. He was punished because he showed off his magical qualities unnecessarily in front of the lay public. The story is well known as it is found in the scripture "Vinayas of Five Different Schools" and is recounted in a number of Pali commentaries as well. The story is

\footnotetext{
${ }^{2}$ This role is also mentioned in the Buddhist sources in Korea in the so-called Pindola-sutra (Cheongbindurogyeong 청빈두로경), in Daejeongjang 대정장, 32, 784b. (Lee 1999, 17)
} 
described in the Ashokavadana sutra as the following (in the translation by John Strong 1979):

Jyotiska, a rich man of Rājagrha, had a begging bowl made from a block of sandalwood, and, wishing to see a display of supernatural powers, he suspended it from the top of a high bamboo pole and organized a contest: whoever could bring the bowl down using magical powers could keep it. Different heretic masters (tirthikas) all try to obtain it, each one pretending in various devious fashions to be endowed with supernatural faculties. But the rich householder is not to be fooled; he wants graphic proof of their powers. Then Pindola happens by together with Mahā Maudgalyāyana. He urges the latter (who is well known as a master of supernatural faculties) to take the bowl, but Maudgalyāyana declines and suggests that Pindola do it instead. Pindola, therefore, flies up into the air in full view of the assembled crowds, tours the city several times, grabs the bowl and brings it to the rich man who fills it and honors him. He then goes back to the vihāra. The whole incident, however, is reported to Buddha who questions Pindola, reprimands him severely for having exhibited his supernatural powers, and then makes a Vinaya rule to the effect that the performance of magical feats in the presence of laymen will henceforth be a duskrta offence. ${ }^{3}$ (Strong 1979, 71-72)

Another famous story from the Ashokavadana shows the importance of Pindola not being dead, and keeping a living connection between the times of Shakyamuni Buddha and the times of the Indian king, Ashoka. Here we can read about the cultic importance of the long eyebrows of Pindola:

Aśoka invites the community of the four quarters to come to him in Pătaliputra where he plans to make them offerings of food and clothes. (pañcavārsika, a quinquennial entertainment of the Sangha). A great number of monks are assembled. However, it is immediately apparent that the reunion is incomplete, for at its very center, the seat of the elder has remained empty. Aśoka, in consternation, asks Yagas, the most venerable elder present: "How is it that the elder's seat is not mounted? Is there here someone else who is older than you?" "There is, O great king" comes the answer. "This seat is that of Pindola Bhāradvāja whom the Buddha designated as foremost of lionroarers." Aśoka is astonished that Pindola is still alive, and asks: "Is it possible for us to see him?" "Great king", answers Yagas, "you will see him now." And there follows the account of Pindola's spectacular arrival. Flying through the air surrounded by several thousands of Arhats in "half-moon formation", he alights in the midst of the assembly and takes his place on the

\footnotetext{
${ }^{3}$ See the various Vinaya accounts in Lévi and Chavannes (1916, 233-47), and the expanded version of the story in The Commentary of Dhammapada, edited by H.C. Norman (1912, vol. 3: 199-203 (in Burlingame vol. 30, part 3: 35-38), Aśokavadāna (in Burnouf 1876, 353).
} 
empty seat, his white hair flowing and his white eyebrows so long that they hang down and cover the pupils of his eyes. (Strong 1979, 71-72) Pindola Bhāradvāja has arrived to receive his food offering, and his presence is clearly a sign that Aśoka's offering is being carried out properly (Strong 1979, 83-84).

At this point there occur some intriguing verbal exchanges between Ashoka and Pindola which provide clues to the interpretation of his cult and legend as a whole. By virtue of the fact that Pindola personally knew (and attained enlightenment under) the Buddha, he establishes a connection between the age of the Buddha and the present, the time of Ashoka. In an actual, more experiential sense, Pindola also makes the Buddha himself present in the here and now situation. This is expressed in the text in a rather intriguing way:

Although Pindola is physically there on the seat in front of him, Aśoka does not immediately see him "face to face". As we have mentioned, Pindola's long white eyebrows hang down and cover the pupils of his eyes, and this, in quite literal terms, keeps them from "eye to eye" contact. (Strong 1979, 84)

This noteworthy physical feature of Pindola, which is mentioned in only one other text, is on the one hand simply indicative of Pindola's great age; he has, after all, been alive for a number of centuries. But the text is so curiously specific about his eyebrows and his eyes that some further interpretation is called for.

The matter becomes clear when it is put in the context of the Buddhist ceremony of the consecration of Buddha images. As it is well known, the climax of any ritual of dedication of a painting or a statue of the Buddha is the moment of the "insertion of the eyes." (Strong 1979, 84) Until they are painted or put in, the image is considered to be lifeless, ritually irrelevant, just a lump of clay or stone or metal. "But with the eyes in, it becomes alive, consecrated, a Buddha-image rather than an image of the Buddha" (Strong 1979, 84).

With his white brows covering his pupils, Pindola at first sits before Ashoka in much the same way as an unfinished "blind" Buddha image. It is, therefore, a moment of great importance in the text when, we are told, with King Ashoka bowing down before him, "the elder lifted up his brows with both hands and gazed straight at the king." (Aśokavadāna in Burnouf 1876, 354) Here, in the cultic situation established by Ashoka and confirmed by his offerings and devotion, the live Pindola is consecrated, or we could say, is sacralized in much the same way as an image of the Buddha. And just like the Buddha image at the precise moment of 
its consecration, Pindola "makes present", ritualistically speaking, the Buddha who is absent in Nirvana (Strong 1979, 85).

\section{Pindola and the Wandering Jew: Eternal Life as a Punishment}

Comparing the legends of the Wandering Jew and the stories of Pindola in Asia we can see that apart from the similar motifs, we cannot find it very convincing to connect them exclusively with a direct link. However, as the nature of legends indicate syncretic tendencies, growing and getting richer with newer and newer elements, layers, thus colouring the traditions. (Birtalan 2011, 210) The comparative tendencies searching for elements connecting Christian and Buddhist traditions were especially popular during the end of the $19^{\text {th }}$ and early $20^{\text {th }}$ centuries.

However, the story of the "eternal wanderer" can help us to identify some layers of traditions and myths which appear in the $17^{\text {th }}$ century Korea in the form of the not very well-known, but widely revered and very visible figure, the socalled "Lonely Saint" (Dokseong).

\section{The Mysterious "Lonely Saint" in Korea}

In South Korea, a so-called "Lonely Saint" is a popular and frequently-worshipped deity. His representations can be found in almost any Korean Buddhist temple, though he remains an obscure and little-understood figure by both Buddhist believers and scholars of Korean culture. They simply associate him to magic and immortality, as this Buddhist figure is often placed in a landscape full of symbols for good health, longevity and fortune symbols, well-known from Korean folkpaintings: mountains, water, waterfalls, clouds, the red sun, deer, cranes, turtles, bullocho-mushrooms and peaches.

In the Joseon era (1432-1910) Buddhism was suppressed in favor of Confucianism, however, Buddhism never ceased to exist, and it produced very interesting iconographies. The styles became more diverse, the materials cheaper, and the patrons were coming from a much wider audience than before. In this milieu, from the $17^{\text {th }}$ century onwards we can see the existence of a particular representation of a Buddhist monk, appearing together with shamanistic and Daoist deities in the furthermost Samseong Halls of the Joseon temple complexes. This monk is called Dokseong or "Lonely Saint", and he is a popular and frequently-worshipped deity in South Korea. His representations can almost 
always be found in Korean Buddhist temples. However, his identity and characteristics remain obscure and little-understood by both Buddhist believers and scholars of Korean culture. His iconic representations are usually placed together with the popular Korean Shamanist/Daoist deities the Sanshin (Mountainspirit) and the Chilseong (Seven Stars spirit) and possibly other non-Buddhist representations in a special shrine for non-Buddhist deities, usually a triad of them, within temple complexes, usually above and behind or next to the Main Halls. However, sometimes he has his own shrine, but again, so far away from the other Buddhist deities.

Who is this Buddhist figure, so far away from the more venerated Buddhist deities? Why does he appear together with the shamanistic and daoist deities? Why can we find very similar background motifs on the paintings aimed to represent him?

To answer these questions I have collected the available sources representing him, putting together my own photographs and the splendid photo-collection of Prof. David Mason, a long-time resident in Korea and an avid collector of the Korean Mountain spirit-representations (Mecsi 2008). ${ }^{5}$

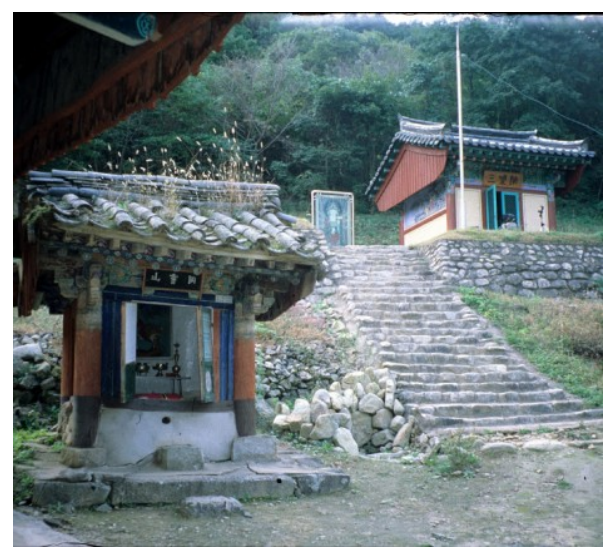

Fig. 1: Sanshin Hall and Samseong Hall, Palgong Mountain, Sudo Temple

We could glean from this that Dokseong is regarded as a somewhat shamanic deity and supplicated for real-world benefits in the Korean Shamanic fashion, but is generally accepted as more of a Buddhist figure than the others enshrined with

\footnotetext{
${ }^{5}$ I would like to thank Prof. Mason for his great generosity to share his photo-collection with me, enabling me to scan the related slides into a digitalized format for this research. All photos in this article are published with his approval.
} 
him, creating a surprising mystery and controversy about his historical origins and religious identity. By looking through the material (which I loaded on a special website), some aspects suggested that he can be connected to one of the foremost Buddhist enlightened-saints (Arhats in Sanskrit), Pindola Bharadvaja, a mythical figure widely held by Northeast Asian Buddhists to be one of the sixteen original and primary disciples of Shakyamuni Buddha. Aspects of this figure's mythology help explain his Shamanistic status and function in Korean temples. We have analyzed these images together with the written sources in order to shed light on the origins of the representation of the Korean "Lonely Saint" and to place them into a wider context, and to rediscover his functional identity.

\section{Description of the Lonely Saint}

Dokseong is always depicted as an elderly man with a distinctly bald head (sometimes protruding a bit at the top) and no hat, with kind but sad eyes, with white hair on the sides of his head and long white eyebrows, usually with no beard or moustache (a shaven face), but occasionally with an "unshaven" stubble of facial hair (never a long beard). He is always depicted seated (cross-legged or with one knee up), wearing Buddhist robes ${ }^{6}$ and barefoot, and holding a yeomju (Buddhist rosary) and/or a wooden staff. In some cases he may be making a mudra (an iconic gesture in Hindu/Buddhist art) with one hand. He is almost always depicted as sitting on a rocky cliff-top beneath a pine-tree, and there is usually a rich background of mountains and forest, with clouds and a waterfall. Near him may also be an incense-burner, books (presumed to be Buddhist sutras), mushrooms, bamboo, flowers, deer, turtles and cranes or other birds (whether perching or flying). All of these are symbols of the powers of natural factors to grant or inspire health, longevity and wisdom to spiritual practitioners in the mountain-forests; they are common in Korean religious paintings and appear with equal frequency in Sanshin (Mountain-spirit) paintings and in other associated artworks. Child-servants may be shown attending him, holding (offering) gifts such as fruits that symbolize longevity, fertility and fecundity, and possibly brewing some sort of tea for him; these are called dongja in Korean, and are common secondary figures in East Asian religious iconography. A statue of Dokseong is usually placed on the altar in front of his taenghwa, as with Sanshin,

\footnotetext{
${ }^{6}$ Often in the "southern" style, with one shoulder bare. He is never painted wearing the gray and brown robes of a $20^{\text {th }}$-century Korean monk. This acknowledges his Indian origins (Mason 1999).
} 
and it often shares iconographic motifs with the painted portrait, although a statue of a Buddha, Bodhisattva or Arhat is sometimes used instead.

Because his representations appear to be portraits of some elderly mastermonk, there are a few Korean Buddhist monks who hold the opinion that he may represent venerable master Payak 波若 (562-613), a renowned monk from the Goguryeo Kingdom ${ }^{7}$ who studied Tiantai Buddhism ${ }^{8}$ on China's Mount Tiantai, gaining enlightenment and died there, never returning to Korea. However, this theory is not widespread among Buddhist believers or scholars, and plays no discernable role in the ritual veneration of Dokseong (Mason 1999, 100).

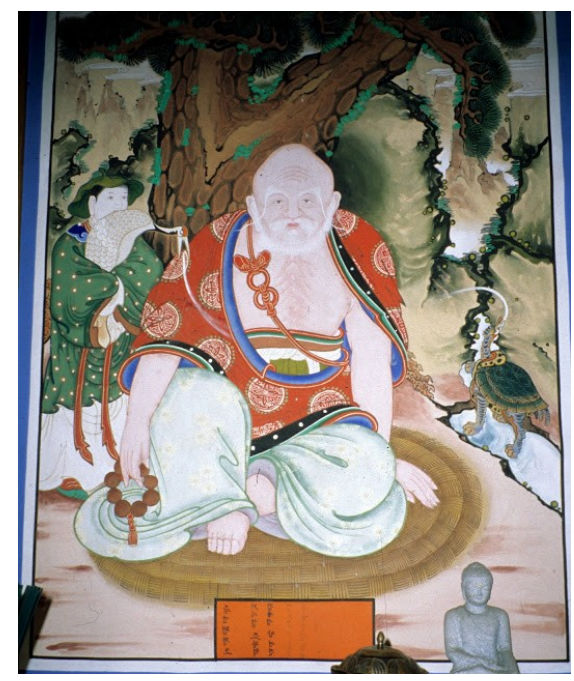

Fig. 2: Lonely Saint, Yeongwol Jeo-dong, Bodeok Temple

There is no evidence from historical or contemporary sources, nor motifs from his iconography, that suggests identification with any other historical master-monk of India, China or Korea itself. However, it is an interesting addition to the reception and appropriation of this figure.

Dokseong is named also as “Naban jonja" 那畔尊者. This name can also be found as an identification written on some of his representations and in later Korean texts. ${ }^{9}$ The meaning of this name can be explained as naban 那畔 “another

\footnotetext{
7 고구려 or 高句麗. One of the Three Ancient Korean Kingdoms, traditional dates 37 BCE-668 CE. 8 天台, Wade-Giles: T'ien T'ai. He is recorded to have studied under Founding-Master Zhiyi (智顗, Wade-Giles: Chih-I, 538-97). Mount Tiantai is now in Zhejiang Province.

${ }^{9}$ Baekpa Geungseon (백파긍선 白波亘旋, 1767-1852): Jakbeopgwigam 작법 귀감 Jebanmun, Dokseong Jaewimun 독성 재의문 獨聖齋義文 (Pak 1993).
} 
way", in contrast with the word joban which means the "ordinary way" according to Lee Ji-kwan (1999).

The first literary evidence in Korea can be found in a ritual text stored at Haeinsa, one of Korea's greatest monasteries, titled the Haeinsa Jebanmun (해인사제반문 海印寺 諸般文) which has a postscript written by Nakam Winul (낙암의눌 落㪜義訥, 1666-1737) dated 1719 referring to the cult of Dokseong as a traditional practice, thus showing that it had already existed well before that time (Lee 1999, 13). ${ }^{10}$

The Haeinsa Jebanmun and other ritual texts also contain other details which help us understand the visual representations, and in addition, they refer to a Buddhist saint, or Arhat, who had very similar features to our Korean Lonely Saint thus connecting it with some Indian and Chinese legends. This way the name "Naban jonja" can be also understood. The features of this "Naban jonja" or Dokseong are particulary interesting as they reflect the elements of the legend of Pindola Bharadvaja, the never-dying arhat who was punished by eternal life. In the Jebanmun texts it is emphasized that Dokseong had very long eyebrows, a motif that appears on most of the images. The distinctively long eyebrows can be seen also on representations of Pindola amongst the 16 Arhats.

As we mentioned earlier, the long eyebrows had a cultic significance as it was indicated in the Indian Ashokavadana sutra, forming a direct connection between the times of Shakyamuni Buddha and King Ashoka.

A story of Chinese origin which also emphashizes the long eyebrows appears in Korean sources (Daejeongjang 50 in Lee 1999):

Tao-an (or Kor. Doan-beopsa) in fearing that his Sutra-commentaries would not be in perfect harmony with the original contents had a dream where an Indian Buddhist monk appeared in front of him whose hair was white and had extremely long eyebrows. This monk has reassured Tao-an about his work and said that he would not enter Nirvana and would help him finish the Sutracommentaries. Tao-an, when he woke up, immediately knew that the monk he saw in his dream was no other than Pindola. (Lee 1999 in Strong 1979, 70)

Elements of some stories about Pindola might have arrived to Korea quite early, as there is an interesting episode in the Samguk Yusa (Supplementary Legends of the Three Kingdoms, written by monk Iryeon in the $13^{\text {th }}$ Century) which might be 
referred to as a parallel of Pindola's story. Derived from Indian sources, this alternate old story shows Pindola's misuse of supernatural powers and explains his exile from Nirvana:

The Chinese translation of the original Indian text (Sumagadhavadana) describes that when hurrying to attend one of the Buddha's meetings, Pindola flew through the air, absentmindedly dragging a mountain behind him as he was mending his robe on the top of the mountain before, planting the needle into the ground with the thread still attached to his hem. This caused a pregnant woman to have a miscarriage when she saw the flying mountain above her head. Thereupon Pindola's supernatural displays could lead to a possible loss of life. (Strong 1979, 74)

The Korean parallel to Pindola's story of dragging a mountain behind him appears in a Samguk Yusa story where it is said that "In Baekje Kingdom a holy monk brought a mountain to the site of Mireuk-sa 彌勒寺, by causing it to fly through the air. Mireuk-sa is dedicated to Maitreya." (Iryeon 1972, 144; Covell in Strong 1979, 76)

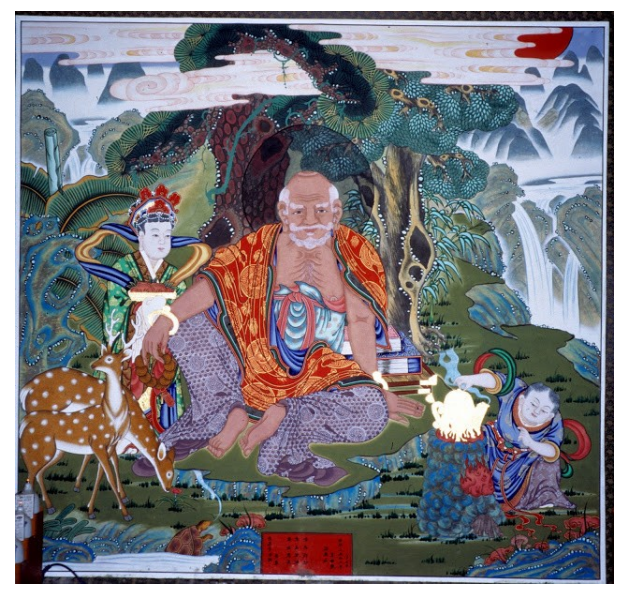

Fig 3: Lonely Saint, Jaeak Mountain, Pyochung Temple, Jinbul Hermitage

In the background of Dokseong images, as we have already seen, we can often find health/longevity/good-fortune symbols well-known from Korean folkpaintings. We can see mountains, waters, waterfalls, clouds, the red sun, deer, cranes, turtles, bullocho-mushrooms and peaches, and we can also encounter the magpies often seen in Korean tiger-paintings. We can speculate that the reason for putting this Buddhist saint in the company of Daoist and shamanist icon-symbols can be connected to this certain Arhat, Pindola, whose legends indicate his connection with magic and immortality, concepts which play very important roles 
in East Asian folk-religions. Therefore, the ubiquitous placement of this Buddhist figure into a landscape full of these symbols from other traditions is further evidence that the original identity of Dokseong is in fact Pindola Bharadvaja.

\section{Pindola in Japan}

In Japan this Pindola figure became popular in a different way. There, from the Edo-period (1603-1868) onwards, he is venerated in a form of a sculpture and it is believed to cure several illnesses. Apart from that, he was also venerated as a patron saint of the refectories following the Chinese tradition. In Japan the sculpted image of Pindola is usually placed outside the temple, mainly at the entrance, whereas in Korea the images of the Lonely Saint are usually placed farther from the main halls, together with the non-Buddhist deities. This can be a sign that indicates Pindola's position as an intermediator between our world and the consecrated realms. In Japan his figure is usually painted red, explaining it as a sign of his gluttony, but this colour often disappears due to being touched by sick people who hope to be thereby cured.

\section{Conclusion}

In Joseon Korea where Buddhism was suppressed by the Confucian ideology, different iconographies appeared and a special syncretism can be observed. From the $17^{\text {th }}$ century onwards we can trace a special figure, called Dokseong or Naban jonja, who is usually represented as a monk in a landscape setting, full of symbols of immortality. His figure is usually enshrined together with shamanist and Daoist images, thus making a special connection with those practices.

The connection is especially strong with them, since he is also used in the same fashion, for real-world benefits and for long life.

From these features we can identify this Buddhist saint with one of the foremost pupils of Shakyamuni Buddha, the Indian Pindola Bharadvaja, who is called Binduro in Korea, and Binzuru in Japan. This particular Arhat, Pindola Bharadvaja, can still be seen and identified in the group of 16 or 500 either in Korea or in Japan, ${ }^{11}$ but he was also worshipped as a separate figure from very

\footnotetext{
${ }^{11}$ The difference in visual represenation between Binduro in Korea and Dokseong is that when Binduro is represented, he is usually shown in the group of arhats, but very often his longer eyebrows make him identifiable within the group. When he is represented as "Dokseong", he is shown alone within a landscape setting referring to immortality.
} 
early times (we have evidence that in China the cult of Pindola existed already in the $5^{\text {th }}$ century CE.). Since he is associated with magic and longevity (he had to stay an Earth until the coming of the Future Buddha, Maitreya), he became surrounded by longevity symbols and placed together with Daoist and folk-deities in Korea. This form of enshrinement is unique to Korea; we have seen how in Japan he is conceived as a healing saint and his figure is usually represented in a sculpted form outside the halls of Buddhist temples from the Edo period onwards. The common feature of these images in Korea and Japan is that both are approachable and very human figures who are intermediators to the holier and more psychologically-distant Buddha-realms. This feature is supported by the background religious texts which discuss Pindola as not entering Nirvana, but living on Earth maintaining a unique direct living connection with the historical Buddha Shakyamuni, whom he used to see face-to-face.

This legend reportedly influenced the European legend of the "Wandering Jew", according to the Japanese scholar Minakata Kumagusu (1867-1941), thus connecting not only the Buddhist traditions with the Daoist and folk-religions in the case of Asian countries, but also reaching to the Western world and colouring Christianity-related myths and legends (Minakata 1899, 123).

\section{References}

Covell, Alan Carter. 1986. Folk Art and Magic: Shamanism in Korea. Seoul: Hollym.

Birtalan, Ágnes. 2011. "Cagān Öwgön és Shou Xing. Újabb adatok a Fehér Öreg mitológiájához." Távol-keleti Tanulmányok 1-2: 3, évfolyam.

Buddhist Legends. 1969. Transl. by Eugene Watson Burlingame. Harvard: Harvard Oriental Series, Vol.30 (original edition: 1921; reprint ed. London: Luzac and Co.).

Burnouf, Eugène. 1876. Introduction à l'histoire du Buddhisme indien, 2nd ed., Paris: Maisonneuve.

De Visser, Marinus Willem. 1923. The Arhats in China and Japan. Berlin: Oesterheld \& Co.

Edmunds, Albert J. 1902. Buddhist and Christian Gospels, 2 vols., 4th ed. Philadelphia: Innes and Sons.

Iryeon. 1972 (13th century). Samguk Yusa: Myths \& Legends of the Three Kingdoms, English translation by Tae-hung Ha. Seoul: Yonsei University Press.

Lee Ji-kwan 李智冠. 1999. “A Study of Naban Shinang. 那畔信仰考, 伽山學報.” Kazan Hakbo 8, April: 12-17. 
Lévi, Sylvain, and Chavannes, Edouard. 1916. "Les seize Arhat protecteurs de la roi." Journal Asiatique 8: 205-75.

Losonczi, Eszter. 2006. A bolygó zsidó legendájának eredete. Kétezer, Irodalmi és Társadalmi Havilap. Accessed June 24, 2014. http://ketezer.hu/2006/06/a-bolygozsido-legendajanak-eredete/.

Mason, David A. 1999. Spirit of the Mountains: Korea's San-shin and Traditions of Mountain-Worship. Seoul: Hollym, Elisabeth NJ.

Mecsi, Beatrix. Dokseong. Picasa Album, Last changed Feb. 3, 2008. https://picasaweb.google.com/bmecsi/Dokseong?authkey=Gv1sRgCNj7mcn06YfB9A $\mathrm{E}$

- Visual database of Dokseong images in Korea. Picasa Album, Last changed Feb. 3, 2008. http://picasaweb.google.com/bmecsi/Dokseong?authkey=9IIfT0kmfdg

—. 2008. "The Power on Images on Texts Re-Examined: The Case of Bodhidharma's Crossing and the Mass-Consumption of Bodhidharma-images in Japan and Contemporary South Korea." Oriental Archive (Archiv Orientalni) 76: 217-49.

—. 2010. "Dokseong: Korea's Mysterious Lonely Saint." Cahiers d'Études Coréennes 8: $357-65$.

—. 2012. "A csodatévő büntetése (The Punishment of the Wonderworker).” Ózon April: $12-13$.

Mecsi, Beatrix, Huylebrouck, Dirk, and Walle, Willy Vande. 2013. "Wandelende Boeddha. Aziatische variant op wandelende Jood." EOS Memo 5: 52-55.

Minakata, Kumagusu. 1899. “The Wandering Jew.” Notes and Queries 9(4): 121-24.

Pak Se-min, ed. 1993. “Dokseong jewimun, Haeinsa 1719.” In Jaebanmun (Comprehensive Archive of Korean Buddhist Rituals) 2: 646b-47b; 682al; 3: 399a. Seoul: Samseong-am.

Strong, John S. 1979. "The Legend of the Lion-Roarer: A Study of the Buddhist Arhat Pindola Bharadvaja.” Numen 26(1), June: 50-88.

Zo, Zayong [Jo Ja-yong]. 1982. Guardians of Happiness: Shamanistic Tradition in Korean Folk Painting. Seoul: Emileh Museum. 